\title{
Negotiating respectability: comparing the experiences of poor and middle class young urban women in India
}

Katherine Twamley, Department of Social Science, University College London, UK. Email: Katherine.twamley@ucl.ac.uk

Juhi Sidharth, Flame University Pune, India. Email: juhi.sidharth@flame.edu.in

Final accepted version for the journal Modern Asian Studies, forthcoming in 2018

\begin{abstract}
This paper draws together two studies, one which explores the intimate relationships of young slum-dwelling Dalit women in Mumbai and the other of young middle class women in Baroda, Gujarat. Using an intersectional lens, we trace the ways that gendered ideals of respectability shape women's freedom of movement and relationships. The comparison produces new insights into the ways that class, caste and location cut across gender to shape young women's lives in India. We argue that the distinctive positionings of the women structure the ways in which they react to gender norms and the means with which they strategise around them. Middle -class young women strike a 'passive bargain', upholding ideals of respectability by shoring up symbolic capital for a 'good' marriage and class privilege. The Dalit women show more active resistance to an ideal which they struggle to achieve, despite heavy control and surveillance over their movement and relationships. However, contrary to previous research, we show that both groups are beholden and lay claim to similar gendered and intimate ideals.
\end{abstract}




\section{Introduction}

Notions of women's honour and purity, tied up with so-called 'respectability', emerged most forcefully in India during the colonial period ${ }^{1}$ and continue to shape Indian women's lives today. Ghare-bhaire-ghare, the inner world of tradition and continuity, was the sanctum to be guarded by (middle-class) women, and bhaire, the hurly burly of everyday life, which was seen as impure and rough, was to be dealt with by men. ${ }^{2}$ The distinction between ghare and bhaire which was reinforced in the colonial period continues to be enforced in novel ways today. For example, while an increasing number of girls and women have entered higher education and employment, Phadke et al argue that women demonstrate respectability primarily through signs that link them to the private space of the family and the home, such as via symbols of matrimony worn on the body. ${ }^{3}$

In tandem, concerns around the preservation of caste hierarchy, have promoted endogamy and also contributed to restrictions on women's movement and parental control over the intimate lives of young people. On Dalit politics in modern India, Anupama $\mathrm{Rao}^{4}$ states, 'Caste is the effect of sexual regulation. Sexual relationships within and between caste communities are a nodal point through which caste supremacy is reproduced and challenged.' The caste system is reproduced by control over female sexuality, traditionally the most stringent over women from the highest castes. ${ }^{5}$ This form of patriarchy gave rise to practices such as sati, child marriages and ban on widow remarriage among Brahmins.

Increasingly, however, class is gaining importance as an indicator of status in India. Since the economic liberalisation of the 1990s, a large consumer-driven middle class has emerged and the accumulation of wealth and consumer goods has become more important as a measure of status. ${ }^{6}$ Nonetheless, caste and class often overlap, with members of the middle and upper classes tending to come from middle and upper caste groups. Furthermore, as argued by Srinivas, dominant uppercaste practices are emulated by the lower castes, especially by those seeking upward social mobility, a process known as 'sanskritization'. In parallel, upper-caste

\footnotetext{
1 P. Chatterjee, "The Nationalist Resolution of the Women's Question," in Recasting Women: Essays in Colonial History, ed. K. Sangari and S. Vaid pp233-253 (Delhi: Kali for Women, 1989).

${ }^{2}$ Ghare bhaire literally means 'at home and outside'. For more detailed discussion see: Heather S. Dell, "'Ordinary" Sex, Prostitutes, and Middle-Class Wives: Liberalisation and National Identity in India," in Sex in Development. Science, Sexuality, and Morality in Global Perspective, ed. Vincanne Adams and Stacey Leigh Pigg, pp187-206 (Durham \& London: Duke University Press, 2005); S. Phadke, S. Khan, and S. Ranade, Why Loiter? Women and Risk on Mumbai Streets (New Delhi: Penguin Books, 2011).

${ }^{3}$ Phadke et al 2011

4 Rao, A. Gender and Caste (New Delhi: Kali for women, 2003)

${ }^{5}$ Chakravarti, U. Gendering Caste; through a feminist lens (Calcutta: Stree, 2003)

6 Beteille, Andre. "Caste in Contemporary India." In Caste Today, edited by C.J. Fuller, pp. 1-31. (Delhi: Oxford University Press, 1996) Donner H (Ed) Being middle class in India: a way of life. (Routledge contemporary South Asia series, Routledge, Taylor \& Francis Group, London, 2011); Parry J. "Sex, Bricks and Mortar: Constructing Class in a Central Indian Steel Town" Modern Asian Studies 48 (5) p1242-1275 (2014)

7 Srinivas, M.N. Caste in Modern India and other essays, (Bombay: Media Promoters and Publishers Pvt Ltd., 1978)
} 
stereotypes of the lower castes as dirty, uncontrolled, and irrational are applied by the middle- and upper- classes to poorer people, regardless of their caste. ${ }^{8}$

With rapid economic growth and exposure to western media, new opportunities in employment and career mobility have arisen for women, as well as for a burgeoning 'new' middle class. A spate of recent studies has explored how women have experienced these changes alongside enduring ideals of feminine 'respectability' ${ }^{9}$. For example, Radhakrishnan ${ }^{10}$ conducted research with professional Indian men and women working in IT in Mumbai, Bangalore, and Silicon Valley in the USA. She argues that a well-educated but family-oriented woman has become symbolic of the modern Indian ideal, embodying as she does both 'tradition' and 'modernity'. Her participants employ, and at times struggle with, the symbolic capital of this 'balanced' ideal to gain respectability, as 'good' middle class Indian women. Similarly Gilbertson ${ }^{11}$ described the careful balancing which young women in Hyderabad negotiate around fashionable 'western' but so-called overly 'revealing' clothes.

In addition to changes in women's employment opportunities, scholars have argued that there has been a shift in intimate practices amongst young Indian people. Young people are placing more emphasis than did their parents on love as a basis for marital relationships. ${ }^{12}$ However, family-arranged marriage, defined as the more 'respectable' marriage form, continues to be the norm across a wide section of society. ${ }^{13}$ Marriage amongst the middle and upper classes remains an important means of social reproduction and exclusion and, as Donner argues ${ }^{14}$, 'talk about different kinds of marriage feeds into constructions of difference - of race, ethnicity, religious community, or caste, as much as the global lifestyles reproduced by class-based identities'.

The above studies focus on middle class women - fewer studies probe notions of respectability and intimate relationships amongst poor women. Perhaps this is

\footnotetext{
${ }^{8}$ S Dickey, "The Pleasures and Anxieties of Being in the Middle: Emerging Middle Class Identities in Urban South India," Modern Asian Studies 46, no. 3 pp.559-599 (2012). Parry, 2014

9 S Daya, "Embodying Modernity: Reading Narratives of Indian Women's Sexual Autonomy and Violation," Gender, place, and culture 16, no. 1 (2009) pp.97-110; A Gilbertson, "A Fine Balance: Negotiating Fashion and Respectable Femininity in Middle-Class Hyderabad, India," Modern Asian Studies 48, no. 1 (2014) pp.120-158; S Mishra, "Recasting Respectability: Habitus, Call Centres and the Modern Indian Woman" (Massey University, 2011); Rupal Oza, "Showcasing India: Gender, Geography and Globalization," Signs: Journal of Women in Culture and Society 26, no. 4 pp. $1067-$ 1095 (2001); R Patel, "Working the Night Shift: Women's Employment in the Transnational Call Centre Industry" (University of Texas, 2008); Shilpa Phadke, "Some Notes Towards Understanding the Construction of Middle-Class Urban Women's Sexuality in India," pp.67-81 in Sexuality, Gender and Rights, ed. G Misra and R Chandiramani (New Delhi: Sage Publications, 2005); S Radhakrishnan, "Professional Women, Good Families: Respectable Feminity and the Cultural Politics of "New" India," Qualitative Sociology 32 pp. 195-212 (2009).

10 'Professional women', 2009

${ }^{11}$ Gilbertson 2014

${ }^{12}$ C.J. Fuller and H. Narasimhan, "Companionate Marriage in India: The Changing Marriage System in a Middle-Class Brahman Subcaste," Journal of the Royal Anthropological Institute 14, pp. 736-754 (2008) J.P. Parry, "Ankulu's Errant Wife: Sex, Marriage and Industry in Contemporary Chatisgarh," Modern Asian Studies 35, no. 4, pp.783-820 (2001).

${ }^{13}$ Henrike Donner, "Doing It Our Way: Love and Marriage in Kolkata Middle-Class Families," .Modern Asian Studies 50 (4) pp.1147-1189 (2016); K Twamley, Love, Marriage and Intimacy among Gujarati Indians. A Suitable Match (Basingstoke: Palgrave Macmillan, 2014).

${ }^{14}$ Donner, 2016 p. 1168
} 
since, as Skeggs comments in the UK, respectability is 'one of the most ubiquitous signifiers of class [...] a property of "others", those who [are] valued and legitimated'. ${ }^{15}$ Traditionally Dalit women are considered to have no honour or "purity"16 - an ideology that has been used to understand the high incidence of rape and abuse of Dalit women in rural India. They are the 'others' against whom middle and upper class women compare themselves. Dalit relationship and employment practices, such as divorce and secondary marriages, have been focused on as 'proof' of the impurity of the communities. Yet as Parry argues, the lower classes are in a bind, since poor women often need to work in circumstances deemed 'unrespectable' (such as construction sites which are associated with lurid tales of women's sexual transgressions). ${ }^{17}$ This in turn is used to justify the higher classes' denigration of such women as sexually promiscuous and lacking honour.

Where working class and Dalit communities do take on middle class and upper caste ideals of honour and intimate practices, authors argue that this is to the detriment of poor women's mobility and freedom. ${ }^{18}$ For example, research has found middle class ideals of companionate marriage are taking hold amongst some upwardly mobile working class groups. ${ }^{19}$ Such marriage practices, far from increasing poor women's participation in marriage, as has been suggested in much of the literature on contemporary middle class marriage practices, have narrowed poor women's relationship options by excluding practices of secondary marriage and divorce. ${ }^{20}$ Furthermore, Still ${ }^{21}$ discusses a new trend among Dalits where young women are educated so that they can marry into middle class Dalit families. As educated wives, however, these women are expected to adopt an upper caste sexual morality: as their responsibility for maintaining the family honour increases, their movement outside the house is curtailed; their language, dress and manners are now expected to speak of shame and modesty. Simultaneously the entry of these women into higher education is accompanied by a pervasive anxiety about illicit affairs that could jeopardize family honour.

In this paper, we bring together two studies which focus on intimate relationships but with two distinct socio-economic groups of Indian women, to unpack how class and caste shape women's experiences of and negotiations with gendered ideals of respectability and intimacy. We take an intersectional approach in our analysis to explore the complex and multiple ways in which gender, caste and social class come together, taking note of the particular historical and socio-political

\footnotetext{
${ }^{15}$ Beverley Skeggs, Formations of Class and Gender: Becoming Respectable (Thousand Oaks, CA: Sage, 1997). p. 1

${ }^{16}$ P. Chowdhry, " Enforcing Cultural Codes: Gender and Violence in North India," in A Question of Silence? The Sexual Economies of Modern India, ed. M.E. John and J Nair pp. 332-367 (New Delhi: Kali for women, 1998).

17 Parry 2014

${ }^{18}$ Still 2011; Parry 2014; Kapadia, K. Introduction: The Politics of Identity, Social Inequality and Economic Growth. In K. Kapadia (Ed.), The violence of development: the politics of identity, gender and social inequalities in India. pp.1-42 (London: Zed Books, 2002).

${ }^{19}$ Parry 2001

${ }^{20}$ See also S Grover Marriage, Love, Caste, and Kinship Support: Lived Experiences of the Urban Poor in India. (Delhi: Social Science Press 2011)

${ }^{21}$ Still C. "Spoiled Brides and the Fear of Education: Honour and Social Mobility among Dalits in South India" Modern Asian Studies Vol. 45, No. 5, pp. 1119-1146 (2011)
} 
context - what Dill and Zambrana ${ }^{22}$ describe as 'the historical modes of incorporation' - and how this informs the experiences and views of our participants. ${ }^{23}$ The first study investigated the construction and experience of love and intimacy among urban Dalit young women, living in a crowded, unhygienic environment in one of the most impoverished slum areas of Mumbai. The second explored the meanings and experiences of love, intimacy and marriage among urban middle class young women in Baroda who lived in up market middle class colonies of Baroda. While the young women in the Mumbai slums belonged to a Maharashtrian Dalit community which has experienced social-economic marginalization for generations, young women in Baroda belonged to middle or upper caste communities which have historically benefitted from higher economic, social and cultural capital.

The comparison brings to the fore similarities in ideals of respectability and appropriate feminine behaviour in intimate relationships across the two groups, but also the differing reactions to and strategies employed by the young women in negotiating with these norms. We show that poor Dalit women are entreated to live to the same ideals of respectability as young middle class women, despite the lack of financial and other resources to hold up an ideal which is associated with higher class groups. Despite, or perhaps because of this, the Dalit women were seen to push the boundaries of 'respectable' behaviour that the middle class young women largely fell in line with. We discuss why this might be the case with reference to the varying positionings and locations of the young women.

\section{Methods}

Study 1: Young Dalit Women in a Mumbai slum

This is an ethnographic project led by Juhi Sidharth, exploring intimacy and relationships amongst young slum-dwelling Dalit women between the ages of 15 and 22 in Mumbai. The data was collected in 2007-8, in ' $M$ ward', one of the largest and most populous slum localities in Mumbai ${ }^{24}$. It is mostly inhabited by Maharashtrian Dalits, many of whom migrated to the city for jobs in the 1970 s.

The research aimed to answer three broad and interlinked questions: What are the ways in which these young women acquire knowledge related to sexuality? How do they understand sexuality? And how does this understanding relate to the everyday lived experiences of sexuality? Data was collected from 42 young women and additional key informants (mothers, teachers and NGO workers). Unstructured in-

\footnotetext{
${ }^{22}$ BT Dill and RE Zambrana, Emerging Intersections: Race, Class and Gender in Theory, Policy and Practice

(New Jersey: Rutgers University Press, 2009). P. 3

${ }^{23}$ A Brah and A Phoenix, "Ain’t I a Woman? Revisiting Intersectionality," Journal of International Women's Studies 5, no. 3 pp75-86 (2004); K Crenshaw, "Demarginalising the Intersection of Race and Sex: A Black Feminist Critique of Antidiscrimination Doctrine, Feminist Theory and Antiracist Politics," University of Chicago Legal Forum (1989) pp 139-67; R Delgado and J Stefancic, Critical Race Theory: An Introduction (New York: New York University Press, 2001).

${ }^{24}$ R. Ramasubban and B. Singh, "Weakness ('Ashaktapana') and Reproductive Health among Women in a Slum Population in Mumbai.," in Cultural Perspectives on Reproductive Health, ed. C.M. Obermeyer, pp 13-37 (New York: Oxford University Press, 2001).
} 
depth interviews, focus group discussions (FGDs), informal conversations and observation were the main tools of data collection. A local NGO helped in recruiting the initial participants for the study, later supplemented by snowballing. Among the older generation, the majority of men in the area were working in the informal sector of the economy, characterized by low-paid, insecure jobs. Many of them worked as construction workers, mechanics, contractors, taxi drivers, auto rickshaw drivers, market vendors, fruit and vegetable sellers. Irregular employment among men meant that women had to take up waged work to fulfill the financial needs of the family. With little formal education, women could only manage to get work in the informal sector. Most of these women were engaged in low paid jobs such as domestic work, catching fish, selling vegetables or in garment factories.

Out of the 42 young women, 19 took part in repeat in-depth interviews. Of these 19 (referred to as 'main participants'), five were 'at home' after dropping out of school; four were in school (one of whom was also working part-time in a clinic); two were studying in the university; and the remaining eight were working in private companies. All the participants were heterosexual. When Juhi first met them, ten of the participants were single and had never been in a relationship. The other nine were in a relationship and five of these were in their second relationship. None were married. None of the partners were included in the study since the focus was on young women.

The first interviews addressed broad questions about home, family and community, and the second probed the participants about their personal relationships with the opposite sex. The FGDs helped uncover the many discourses related to gender and sexuality in the slum area and the wider city. The FGD covered perceived controls faced by young women in the area and the beliefs, ideals and expectations associated with love, sex and marriage. In addition, the participants were observed in their real life settings to gain an understanding of their context and background.

The process of data analysis largely followed methods of thematic analysis, ${ }^{25}$ with some case study analysis to interrogate the nuances of individual experiences. ${ }^{26}$

\section{Study 2: Young middle class Women in Baroda, Gujarat}

The second study, led by Katherine, was a two-site ethnographic study comparing understandings of love, intimacy, and marriage amongst heterosexual men and women of Indian Gujarati origin brought up and living in the UK, with a similar group brought up and living in India. The research set out to explore how those who see themselves as 'Gujarati' or 'Indian' in two very different contexts understand and negotiate relationships and marriage. The principal method of data collection was repeat in-depth interviews with 18 main participants ${ }^{27}$ in Baroda (India) in 2007, and

\footnotetext{
${ }^{25}$ Braun, V. and Clarke, V. Using thematic analysis in psychology. Qualitative Research in Psychology, 3 (2). pp. 77-101, (2006)

${ }^{26}$ L. Cohen, L. Manion, and K. Morrison, Research Methods in Education (London: Routledge Farmer, 2000).

27 'Main participants' were those who fulfilled the main criteria of interest (Gujarati origin; aged between 20 and 30; middle class background). These all participated in repeat in-depth interviews and observations. Peripheral participants included priests, parents, teachers, matchmakers and other young people who were engaged in the study to a lesser degree.
} 
12 in London (England) in 2008. Participant and non-participant observation and focus group discussions were also carried out.

For the purposes of this article, we draw on the data collected with young women in Baroda. Participants were aged between 20 and 30 years of age, in various stages of relationships; four were single, five married and one was in a relationship. Participants were recruited through university societies and notice boards, snowballing and key informants. They lived in houses or apartments in 'colonies' around the more affluent parts of Baroda, with all having access to their own motorized vehicle (mostly scooters) and domestic help. They had all completed school and all bar one were university educated, and worked in or aspired to jobs in the private sector, such as in business, IT and finance. As such they can be said to be members of the 'new middle class' in India ${ }^{28}$. The term 'new middle class' not only refers to the new occupations which make up this group (previously the middle classes in India were more typically associated with civil service jobs or the professions), but also the 'project' or 'discourse' within which members of this group engage - of upward mobility, globalization and consumerism. ${ }^{29}$

Katherine conducted between three and five interviews with each main participant. These interviews followed a flexible semi-structured topic guide; the first two interviews addressed family background, upbringing, parents' marriage, friendships, and relationship experiences. The third interview addressed issues around sexuality and physical intimacy. Where women participated with their partner, the couple were interviewed together in the first interview and separately in subsequent interviews. Interviews were primarily conducted in English - issues around the use of interpreters and translations are discussed in more detail elsewhere. ${ }^{30}$ The analysis broadly followed the methods of constructivist grounded theory, as outlined by Kathy Charmaz. ${ }^{31}$

\section{Comparing middle-class and Dalit young women}

In order to compare and contrast the data collected from the two studies, we undertook an intensive reading of one another's work, searching for common themes and divergences. In applying an intersectional approach, positioning was used as a conceptual tool to analyse the ways participants are positioned, and position themselves and others across the two studies. This approach recognises that individuals can actively align themselves with subject positions within a range of discourses to construct an account of the self to bring particular benefits, such as

\footnotetext{
${ }^{28}$ Leela Fernandes, India's New Middle Class: Democratic Politics in an Era of Economic Reform (Minneapolis: University of Minnesota Press, 2006); C.J. Fuller and H. Narasimhan, "Information Technology Professionals and the New-Rich Middle Class in Chennai (Madras)," Modern Asian Studies 41, no. 1 pp. 121-150 (2007).

${ }^{29}$ S Srivastava, (ed), Sexual Sites, Seminal Attitudes: Sexualities, Masculinities and Culture in South Asia (Delhi: Sage, 2004).

${ }^{30} \mathrm{~K}$ Twamley, Love, marriage and intimacy among Gujarati Indians: A Suitable Match (Basingstoke: Palgrave Macmillan, 2014)

${ }^{31}$ Kathy Charmaz, Constructing Grounded Theory. A Practical Guide through Qualitative Analysis (London: Sage, 2006).
} 
social status or social acceptance. ${ }^{32}$ There is space, therefore, to unpack both how and why individuals position themselves in particular ways. Our comparative analysis explores how these positionings operate in the different locales, and how the contexts shaped these positionings. This is relevant for the gendered ideal of 'respectability' in a context where previous studies have shown that women's position in Indian society is shifting under economic liberalisation and globalisation. We examine how the participants position themselves in terms of respectability and class, and how they deal with the positionings others place them within.

Below we outline separately the findings on respectability and relationships in the two studies, and we then move on to a discussion on the commonalities and differences, and how their positionings influenced the differing outcomes and strategies employed by the women. First, however, we consider how the positionings of the two researchers who conducted the studies may have shaped the data and analysis: Juhi is from India but being from a different state (Gujarat) and class group, undertaking a $\mathrm{PhD}$ in a foreign university, ensured that she was treated like an 'outsider' in matters of the slum. Her unmarried status also positioned her as a 'girl' which aided her efforts to establish rapport with her young participants. She wore a simple cotton salwar kameez during the visits to the slum, thus 'performing' a localized form of 'respectability' and gaining acceptability from elders. Katherine was also positioned as an outsider. As a white Irish woman she was quite evidently 'foreign' in a small city where there are few foreigners. Her status as an unmarried woman travelling abroad alone sparked many conversations, with participants describing her as 'obviously strong and independent'. Outsider status was cited as a reason in both studies to trust the researchers, in particular with stories of potentially illicit behaviour (such as premarital relationships). Katherine's foreign-ness, however, may have produced a reticence to denigrate 'Indian' customs - such as arranged marriage - in front of a foreign 'other'. Their expressed positive views of arranged marriage, however, are backed up by detailed ethnographic fieldwork and, as we discuss below, have been similarly noted in other research with middle class young women. ${ }^{33}$

In addition, it is worth noting that the participants from the Mumbai study are slightly younger (aged between 15 and 20 years) than those from Baroda (aged between 20 and 30 years). The differences in age reflect the differing aims of the studies - in Mumbai to understand and inform young women's sexual learning and experiences of intimate relationships and in Baroda to examine a cross-section of intimate relationships and pathways to marriage. It is difficult to assess to what degree the differences we found were shaped by age, but we feel it unlikely that this was a strong factor. While adolescence is notionally associated with rebellion, and therefore potentially more active questioning of tradition such as witnessed amongst Mumbai participants, in general we found that younger participants in Baroda were no more similar to the older participants in Mumbai, despite having the same or almost the same age.

\footnotetext{
${ }^{32}$ P. Holden, Autobiography and Decolonization: Modernity, Masculinity and the Nation-State (Madison: University of Wisconsin Press, 2008); J Parkes et al., "Between Tradition and Modernity: Girls' Talk About Sexual Relationships and Violence in Kenya, Ghana and Mozambique," Comparative Education 52, no. 2 pp157-176 (2016).

${ }^{33}$ See Phadke et al 2011
} 


\section{Findings}

\section{Performing respectability: Dalit slum-dwelling women}

Respectability was seen to be of critical importance for participants in Mumbai, imperative for a good reputation and necessary to be able to negotiate a match with a 'good' husband. As discussed, however, respectability is notionally connected with middle class and upper caste women and not with women from poor and Dalit backgrounds. Participants' precarious attachment to a respectable reputation can be seen via the defensive positions which the women recount, constantly negotiating with the researcher and others their positioning as a 'respectable' and not a faltu (loose) woman. One participant, for example, told Juhi 'Whether we do anything or not, we lose our reputation.' (Arti, 19 years)

Much talk in the slum was observed to be around the reputations, many sullied, of young women, and how the young women attempted to uphold 'good' reputations of themselves. One means of attempting to attain respectability (and a financially secure future) was via education and work that would give them an elevated status and reputation. However, this was very difficult as most participants were unable to complete school education ${ }^{34}$ which is needed for a well-paying 'respectable' job. Domestic work, which most of their mothers engaged in and which according to caste-based occupational hierarchy has traditionally been associated with Dalits, was considered to be undesirable by the young women. Participants preferred to work in a school, nursery, hospital or company. Nevertheless, the participants referred to themselves as 'middle class' despite the context of poverty in which they lived, thus distancing themselves from the stigma associated with being perceived as 'lower class' and, we argue, as part of a project to claim a respectable identity. ${ }^{35}$

The precarious nature of young women's reputation resulted in heavy surveillance from family and other community members. Essentially movement was restricted for the purposes of accessing education or work. Mobility for pleasure and leisure was far more contentious in the slum area. So-called 'loitering' or 'hanging out' in the slum area (ghoomna-phirna) or making frequent visits to the grocery store or community toilet invited critical comments from others in the area. Elaborating on this issue, Mitra (18 years) said

My brother does not even allow me to go to the bathroom. If it is crowded, it is going to take time. He then says "why did you get back late?" He hits me and tells me that I should not be away in the bathroom for so long.

As can be seen here, violence and the threat of violence were used by brothers to enforce the surveillance of women's movement. ${ }^{36}$ Young women without any work or

\footnotetext{
34 Most young women lost their interest in education after failing in Class 10 Board examinations (national examinations taken at age 15). Other women dropped out of school when their labour was needed at home. In a small number of cases, young women were pulled out of school by their families and relatives when they were suspected of being involved in romantic affairs.

${ }^{35}$ See also in Dickey 2012.

${ }^{36}$ While much scholarly literature and media reports have focused on violence towards Dalit women perpetrated by upper-caste men, our research concurs with emerging recent research on Dalit male violence towards Dalit women, which has been attributed to an adoption of 'hyper-masculinity'. Still; Anandhi, S.J, Jeyaranjan and Krishnan R 'Masculinity and Domestic Violence in a Tamil Nadu Village' in Men, Masculinity and Domestic Violence in India: Summary Report of Four Studies. (Washington: International Centre for Research on Women (ICRW), 2002) https://www.icrw.org/wp-
} 
education were under particular surveillance and restrictions since there was no apparent 'respectable' reason for them to leave the home. For example, Ramya (17 years) had dropped out of school at year 8 , three years before meeting Juhi. In an indepth interview, she complained that she was often taunted and criticised by elderly women in the area for 'sitting at home'. The implication is that as a young unmarried young woman, she had no productive means to spend her time. Such supposed idleness led to suspicions of affairs:

They (neighbours) tell me that you don't go to school, you keep roaming around, and talking to boys. (Ramya, 20 years)

Young men, on the other hand, enjoy unlimited freedom of movement and closely monitor the movements of their sisters. Young women were not allowed to use mobile phones in a bid to control their communications with others. Cousins and elder brothers were helped by their male friends in this daily surveillance of young women. The constant scrutiny and gossip about young women was made possible by the specific geography of the slum area, characterised by cramped and crowded living conditions that give little privacy.

In addition to restrictions on women's mobility, women reported restrictions on their clothes and behaviour, as Anita (18 years) here describes:

We can wear it (jeans) at home. If we wear it outside, we will be called faltu. We will be called faltu merely for wearing these clothes. That is the reason parents do not allow us to wear these clothes. This is how it is in this area.

Parents, especially mothers, advised young women on issues related to dress, speech and conduct, emphasising their positioning as 'young girl' in the slum. In the quote below, Sanjana (16 years) describes the advice she has received from her mother:

My mother tells me not to talk too much. You are a $\operatorname{girl}^{37}$ so you should behave like a girl. A girl is supposed to remain guarded (ladki la zati la gabhrayela paje). My mother tells me to sit quietly and cover my body properly. "You are a girl so behave like a girl."

Like, Sanjana, other young women also stated that they were urged by their mothers to wear 'modest' Indian clothes outside the house. Modest Indian clothing usually referred to loosely fitted salwar kameez with a dupatta (long scarf) covering the chest.

The young women were critical of the restrictions placed on them and especially the restrictions on mixing with members of the opposite sex. In their opinion, 'upper class girls' (living in colonies) had more freedom related to dating and mixing with the opposite sex compared to girls in the slum area. Moreover, they felt that 'upper class girls' had the resources that enabled them to be discreet about their sexual life (money to go to a private clinic for abortion, for instance). Commenting on a television program called 'Naya roop, Nayi zindagi' (New look, New life), Sanjana said that she did not want a 'new look' but wanted a 'new life'. When probed, she said 'new life means a friendly environment... if I am talking to a boy it does not mean that I am having an affair with him. Even if he is a brother, people are out to

content/uploads/2016/10/Domestic-Violence-in-India-4-Men-Masculinity-and-Domestic-Violence-inIndia.pdf

${ }^{37}$ Girl or ladki is a common referent for any unmarried woman, regardless of age. 
ruin reputations'. Like Sanjana, many other young women expressed their anger and frustration at the relentless gossip and labeling which took places in the slum. Describing the slum area as a 'gutter' and a 'jail', young women stated time and again that they wanted to move into more affluent areas in the city.

Several participants also questioned notions of 'faltu' as defined by community elders, arguing in favour of premarital relationships, for example:

Vanya (17 years): If a girl is in love with a boy and is going around, why do other people have a problem? How can you call her faltu?

This criticism can be seen as an attempt by young women to question the notion of respectability as defined by community elders in the slum area. This criticism also needs to be understood in light of the reality of marriages in the slum area. Marriage was viewed as an institution marked by persistent violence and drudgery with most young women having witnessed their mothers and sisters facing domestic violence on a daily basis. Discussions on marriage unfailingly evoked stories of violence, abuse and economic hardship. For most of the women, marriages did not lead to upward economic or social mobility and many anticipated marriages devoid of intimacy:

People who are in love roam around before marriage. They experience intimacy (apnapan) but they do not experience it after marriage. Anjali (20 years)

When I get married, my life will go into it. Do this and that for him (husband), endure his tantrums. Sanjana (16 years)

Moreover, for most young women, romantic relationships also helped them expand their freedom of movement as boyfriends paid for all the expenses during trips within the city.

However, while the participants proclaimed pre-marital love to be acceptable, they did not abandon notions of respectable sexuality/relationships, rather they delineated a particular form of relationship which they deemed to be respectable. The young Dalit women argued that 'serious' love was acceptable, while 'time pass' love was more akin to faltugiri or 'loose' behaviour which was not acceptable. "S8 'Serious love' referred to relationships that would lead to marriage. ${ }^{39}$ Such serious relationships should happen away from the slum, in a 'discreet' manner. Young women who roamed with their boyfriends in the slum area were criticized by the participants in the study. This kind of conduct was considered to be unacceptable because it jeopardized the reputation of the woman's family in the area.

To circumvent such restrictions on their movement and relationship practices, the young women used a number of strategies. A few women managed to acquire their own mobile phones, unbeknownst to their families, usually gifts from their

\footnotetext{
${ }^{38}$ See also: L. Abraham, "Bhai-Behen, True Love, Time Pass: Friendships and Sexual Partnerships among Youth in an Indian Metropolis," Culture Health \& Sexuality 4, no. 3 pp 337-353 (2002).

${ }^{39}$ This notion of love in which the first relationship leads to marriage has also been highlighted by Perveez Mody (2008) in her study on love marriages in Delhi. Mody argues this closely follows ideas about female sexuality being given to just one man (p. 12). P Mody, The Intimate State: Love-Marriage and the Law in Delhi (New Delhi: Routledge, 2008).
} 
boyfriends. Clandestine meetings with young men were arranged via subterfuge, under the guise of more 'respectable' outings. For example some women pretended to attend temple, when really they were meeting boys or friends outside of the slum. As intimated above, completing education and getting a relatively well-paid job, could facilitate freedom of movement via the increased economic resources and the trust that such 'serious' work provoked, thus providing more freedoms to mix with boys. Another means to acquire a respectable and trustworthy reputation was by appearing and acting like a 'good girl'. Clothes emerged as an important signifier of respectability and participants reported actively choosing such traditional dress in order to achieve a better reputation.

Participants expressed equivocal attitudes towards different forms of marriage. Unlike research conducted with wealthier middle class young women where a strong preference for arranged marriage has been reported, ${ }^{40}$ in the slum the young women were more concerned with the kind of spouse that could be found. The importance of choosing the 'right' boy who was 'educated and engaged in regular paid work' was emphasized. While the participants reported being actively engaged in the selection of their future spouse in tandem with their parents in arranged marriage processes, parents are still reported as the ultimate arbiters of a suitable match, and the young women were not always in agreement. Several young women were, in fact, suspicious of parents' ability to really choose well, as Vanya (17 years) discusses here:

Parents don't know if the boy smokes...parents should see if the boy is good. Some parents don't think before getting their daughters married direct sometimes. But they should think before getting the daughter married. There are many such examples here.

Vanya and her friends challenged the idea that one should go for arranged marriage simply to uphold family honour and are critical of parents who do not put in sufficient effort to find the 'right' groom for their daughters.

Some participants then felt that a love marriage may be more trustworthy in selecting the 'right boy' as Shobha (17 years) explains:

In a love marriage, we know about the hobbies of the person and so there are no problems in the future. In an arranged marriage, my parents would not know what the boy did in the past, what was his nature or about his personal life. My parents would only see his house, the rooms in his house and how much he earns. That's it! But we would know everything about our boyfriend's life.

While Shobha expresses these views, she chose to opt for an arranged marriage when she realized that her boyfriend did not fulfill the criteria of a 'right' groom. Thus, while women expressed misgivings over whether their parents really were capable of choosing an appropriate groom, love marriage was also deemed to be risky. An important consideration for participants was the security and support of the natal home which may be withdrawn in the case of a love marriage. ${ }^{41}$

\section{Embodying respectability: Middle class women in Baroda}

\footnotetext{
${ }^{40}$ See Donner, 2016

${ }^{41}$ Similar findings were uncovered in Grover, 2011.
} 
Baroda middle class women reported having more opportunities to mix with young men than participants in Mumbai, and more freedom generally to manage their own time. They had their own mobile phones and many of them had their own scooter or had access to a family scooter. Such items allowed them to converse privately with others and to 'roam' around the city with friends. Attending university was one major way of managing their own time, since classes were sporadic throughout the week leaving them free time to fill as they chose. Katherine observed women at late night parties and discos, and in the evenings in coffee shops and malls. But while young middle class women had considerably more freedom to manage their time than the Dalit young women reported in Mumbai, they had less freedom and more regulation than their male peers. Far fewer young women than men were observed out in the evenings and in non-privatised spaces.

According to Katherine's participants, women's temporal and geographical absence from particular spaces was down to self-surveillance, rather than parental and community monitoring observed in the $\mathrm{M}$ ward slum. The young women claimed that their parents were 'very frank', allowing them to freely mix with boys because they trusted that they would not do anything inappropriate. Participants were adamant that their parents rarely if ever exercised any authority over them, apparently not imposing any restrictions on them. For example, in the first interview, Katherine asked participants about their relationships with their parents when they were growing up, and whether they were allowed to socialise with members of the opposite sex, go out to parties and so on. The following is emblematic of the kinds of responses received:

Katherine: And were your parents strict when growing up?

Swati: No, neither of our parents were strict, they have allowed us to do what ever we want to do in our lives. Because, and they are confident that whatever we will do, we will do it in right way, we will not do it in wrong way. So they haven't kept any of the restrictions or anything. (Swati, 26 years)

Gradually it became apparent that 'restrictions' on young people, and particularly on young women, were associated with a 'narrow minded' and old fashioned mentality, as Muktha here explains:

M: So they [parents] trust me. And I also not, eh, break their trust. So they allow everything I want. But I am also used to tell them everything. [...] Everything I tell them so they trust, no I am not doing anything which they don't like. And em, you know na? There is narrow-mind, broad mind? What narrow mind means?

Katherine: Not really.

M: Narrow minded means very narrow mind, they are not thinking of outside world, what is going on, what today's people are want to do; "young women are only for home, they should not study more". My father and mother has, they have give well [good] education to me but before, some parents are "girl are only for 10th - 12th education and then for marriage, children and all that." This is narrow minded. (Muktha, 22 years)

Muktha explains how she does not 'break' her parents' trust. They 'allow' her anything, with the understanding that she will behave well. She argues that such mutual trust signifies the 'broadminded' nature of her parents. Where restrictions are mentioned, these are posed as overly generous and therefore not restrictions at all, as seen here with Nirali:

Katherine: What about parties, do your parents mind if you go out late to parties? 
Nirali: They always think I will be home after 11 and I always come home at around 10! They say to me, 'why you left the party!?' I say, 'the party is over, why can't I come home now?!' They say, 'oh, it's over now? We thought it will be over at 11!' They never stop me from doing anything, they are always very frank with me. (Nirali, 23 years)

This is not to say that no young middle class women were engaging in pre-marital relationships or lying to their parents about their whereabouts, but on the whole such levels of activity were found to be low, and frowned upon by Katherine's participants (male as well as female), who predominantly presented their (respectable) behaviour as in-line (or surpassing) parents' expectations.

In part the discourse around a 'lack of rules' relates to women's self-positioning as 'modern' since autonomy is notionally associated with 'modernity' and the 'new' Indian middle classes. ${ }^{42}$ Women in Baroda spoke enthusiastically about the importance of a 'modern' outlook and disparagingly of 'backward' sexist men from rural areas and lower castes. They sought to marry an educated man who they thought would be more likely to have an egalitarian attitude, as one focus group participant commented, 'If you are educated you can try to find someone who will allow an equitable relationship.' Less educated, rural, and lower caste men were stereotyped as sexist and 'backward'. By denying restrictions placed on them, the young women demonstrate their 'forward thinking' family background. The ways in which they adhere to 'good' behaviour (by not going out late and avoiding relationships with inappropriate young men), give the impression that there is no conflict between expectations and behaviour. Furthermore, their ability to move around was enabled by their access to new locations of consumption, 'respectable' private public spaces such as coffee shops and malls. ${ }^{43}$ Women thus appear to internalise the restrictions placed on them, embodying the very notion of feminine respectability.

Such strategizing can also be seen in participants' narratives and practices around intimate relationships. As mentioned above, few expressed an interest in premarital relationships and most claimed to generally avoid such behaviour. They contrasted their relationships with the 'cheap' behaviour of those that take part in 'time pass' relationships. Those that did report having a boyfriend before marriage, characterized their relationships as 'pure love', a chaste kind of love devolved of any sexual connotation which should ultimately culminate in a marriage approved by parents. According to Swati, 'educated' young people are more likely to have such 'pure' relationships. Some parents signal their willingness to arrange a marriage with someone of their daughter's choosing. For example, Muktha's parents have told her they will support her choice if he is an 'appropriate' match. In an interview with the mother, she said:

This marriage [self-selected] is okay but my thinking is that the boy must be good. Love is not blind. There is some criteria for love marriage: The boy has good education, good family background, good condition... The thinking should be good . the right steps should be made.

Likewise, Muktha (23 years) said that she would look for a husband with 'good nature, good job, good background, good job, good family.' These are the parameters her parents have laid out, which she too has internalised; for her, a 'good match' is

\footnotetext{
${ }^{42} \mathrm{~J}$ Belliappa, Gender, Class and Reflexive Modernity in India (Basingstoke: Palgrave, 2013). M. Liechty, Suitably Modern: Making Middle-Class Culture in a New Consumer Society (Princeton: Princeton University Press, 2003).

${ }^{43}$ Henrike Donner, "'One's Own Marriage': Love Marriages in a Calcutta Neighbourhood " South Asia 22, no. 1 pp 79-94 (2002); Twamley, 2014
} 
one with a financially secure man from a 'good family'. As with other participants, Muktha not only adheres to her parents' stipulations, but also believes that a marriage between two members of similar status and background is more likely to last. Only with such a man will Muktha attempt to form a marriage, and physical contact during such a courtship will be kept to a minimum. In fact, these 'love-arranged' marriages were strikingly similar to arranged marriages, such that decisions to marry were generally facilitated with parents only after a handful of meetings between the couple.

But, despite some evidence of parents who were willing to facilitate a so-called 'love-arranged marriage', such as seen with Muktha's mother above, on the whole participants in Baroda reported a preference for a 'proper' arranged marriage. Lovearranged marriages entail risks that some women were not willing to take - such as the relationship breaking down before the marriage being arranged, or parents refusing to agree to the match. Then in attempting to create marriages which meet both romantic and 'traditional' ideals, young people 'arrange love' within the more socially acceptable arranged marriage process. They did this by infusing arranged marriage processes with a romantic interpretation and courtship rituals. For example, the engagement period directly after initial introductions (usually just three sometimes chaperoned meetings), lasted for six months and was described as a very 'romantic' and 'free' period in participants' lives. This courtship after engagement, which contains romantic dating rituals akin to those typically seen in western contexts, serves to imbue the marriage with romantic love, despite the formal family arrangements which initiated the marriage. As Swati (25 years) said,

Love marriage love is there before you get married, before you decide, arranged marriage is after you decide love comes.

It is after the decision to marry that love comes; participants choose a partner according to certain criteria and then expect (or perhaps provoke) a particular form of idealized romantic love for their future spouse. In this way, young women in Baroda continue to conform to ideals of respectability, by avoiding premarital relationships and continuing the tradition of arranged marriage, while also carving out a romantic courtship and self-styled 'companionate marriage'. These young women on the whole do not challenge the restrictions or traditions which their parents and family set out around their movements and relationships, even when they appear to work against their own desires, but rather work within these limitations, indeed seemingly embracing them.

\section{Discussion}

Saba Mahmood questions to what degree 'resistance' to patriarchy can and should be universally understood across different contexts. Drawing on the example of Egyptian women's participation in a revivalist Islamic movement, she demonstrates how her participants 'work on themselves to become the willing subjects of a particular discourse', even when it may seem to run counter to their emancipation. ${ }^{44}$ In parallel, Belliappa $^{45}$ argued that 'western' concepts of individual subjectivity are not

\footnotetext{
${ }^{44}$ S Mahmood, "Feminist Theory, Embodiment, and the Docile Agent: Some Reflections on the Egyptian Islamic Revival," Cultural Anthropology 6, no. 2 pp. 202-236 (2001). P. 210

${ }^{45}$ JL Belliappa, (2013) Gender, Class and Reflexive Modernity in India. Basingstoke: Palgrave Macmillan
} 
applicable in India, where a more relational model can be seen to be engaged with by women. For her participants, family and community mediate the individual sense of self, so that women make decisions with family in tandem. ${ }^{46}$ Both of these works go some way to explain the actions (and inactions) that participants in Baroda and Mumbai undertake, seemingly feeding into patriarchal structures by aspiring to and drawing on gendered notions of 'respectability' which rebound on their families and communities. The women in Baroda in particular appear to reject individual autonomy over and above adherence to family preferences in relationships. However, we have found Kandiyoti's theorisation of 'patriarchal bargaining " 47 to be more useful in this context. Patriarchal bargaining describes the ways in which women strategise 'within a set of concrete constraints' across variations of class, caste and ethnicity. ${ }^{48}$ Kandiyoti delineates different kinds of patriarchal systems and women's 'passive' or 'active' resistance to them. She argues that in the Indian context a more 'classical' patriarchal system and passive resistance can be observed. She draws on the example of women who submit to more passive behaviour as daughters-in-law and later work to similarly marginalise their own daughters-in-law thereby developing a powerful position for themselves as the 'mother-in-law' in later life. As Kandiyoti states, 'These individual power tactics do little to alter the structurally unfavourable terms of the overall patriarchal script, [rather] women become experts in maximizing their own life chances'. ${ }^{4}$

We have identified similar strategies in our data. For example, young women in Baroda appear to embrace the particular limitations which are expected of them as 'middle class respectable' women - that is to not 'roam around' or engage in premarital relationships - while simultaneously denigrating women from 'lower class' groups who they typify as engaging in such activities. In this way, Baroda participants maintain their status as middle class respectable young women, without in any way challenging notions of respectability or the unequal expectations of young men and women. These findings resonate with those uncovered by Phadke and colleagues in their study of young middle class women in Bombay. They wrote that their participants 'revise their definition of what constitutes fun', ${ }^{50}$, working around the limitations imposed on them by their parents, they claim to enjoy themselves within the reduced spaces and stipulations they are told to adhere to. Indeed, they argue, 'Instead of seeing this constant strategizing as a limitation on her movements [...] the good middle-class girl takes pride in her skill in 'handling her family', dodging the male gaze, and still managing to have fun. ${ }^{, 51}$

Meanwhile women in Mumbai, notionally positioned outside of discourses of 'respectability' by Baroda participants, are nonetheless judged and surveillanced within those terms. Research by Rao and Still suggests that a performance of respectability is one way which Dalit women (and their families) have pursued a 'life

\footnotetext{
${ }^{46}$ A relational approach to agency is gaining popularity across British (and other) sociology, see Roseneil S and Ketokivi K, Relational Persons and Relational Processes: Developing the Notion of Relationality for the Sociology of Personal Life Sociology Vol. 50(1) pp.143-159 (2016) for a more indepth discussion.

${ }^{47}$ D Kandiyoti, "Bargaining with Patriarchy," Gender and Society 2, no. 3 pp 274-290 (1988).

48 ibid, p. 275

${ }^{49}$ Ibid, p. 280. In contrast, active resistance, as may be surmised by the title, refers to a more explicit resistance against patriarchy. Kandiyoti gives the example of women in Sub-Saharan Africa who left their husbands after they had appropriated their wives' land and farm production (p. 276).

${ }^{50}$ Phadke, Khan, and Ranage, P. 169

${ }^{51}$ Ibid, p. 169
} 
of dignity ${ }^{, 52}$, likely the more affluent of the Dalit community who are desirous of social mobility. That our respondents self-identify as 'middle-class', despite the conditions of poverty in which they live and their lower caste status, indicates that the Dalit participants in Mumbai too are desirous of upward social mobility. Respectability, as argued by Still, then becomes one perceived way, perhaps the most accessible way, of achieving this.

The young Dalit women in Mumbai performed aspects of respectability, such as wearing traditional Indian dress or mixing with young men 'discreetly', while situating themselves apart from 'loose' women who, they argue, explicitly break such rules by flirting with boys openly. These findings echo those of Sameera $\mathrm{Khan}^{53}$ in her study of young Muslim in Mumbai. She found that women desirous of pursuing higher education and careers had to follow 'conservative' community norms of curfews, dress codes and veiling. In following these norms, they appear as 'good' women not transgressing cultural boundaries. Many women respondents felt that by appearing 'good', such as by being veiled, they could better negotiate some level of public access with their families and community.

If we compare the young women interviewed by Juhi in the Mumbai slums with those from Baroda, the former appear to take more risks and were more vocal in their challenges to the limitations imposed on them, with many using performances of respectability (rather than wholeheartedly conforming to them) in order to achieve their own goals. In this sense, they were more 'active' resistors than the young women of Baroda. Their 'deferential performance' does not appear to imply 'deferential attitudes ${ }^{54}$ and thus less an endorsement of the status quo, as seen from the women in Baroda.

Why such differing approaches? We argue that there are three main factors which shape how and why our participants resist and conform to notions of respectability in different ways:

\section{Class and caste}

As discussed in the introduction, traditionally upper caste codes have resulted in the strictest restrictions placed on upper caste women in a bid to ensure endogamous marriages. However, as we have seen, such norms are being emulated by the lower castes, especially when seeking upward social mobility. As Dickey ${ }^{55}$ puts it 'hegemonic high-caste ideals [...] inflect class attitudes, values, and practices... they are now clearly middle-class values and are shared broadly across people who identify themselves as middle class, regardless of their caste.' While traditionally Dalit women have had more freedom of movement, in part through necessity for employment, in our data it appeared that the strictest restrictions were placed on the lower caste and class women. We argue that the Dalit women's caste reputation as without honour and their low-income meant a tenuous link to the middle-class status they lay claim to. This resulted in the young women's positioning as respectable more precarious and

\footnotetext{
${ }^{52}$ Rao N, "Marriage, Violence and Choice: Understanding Dalit Women's Agency in Rural Tamil Nadu" Gender and Society 29( 3):410-433, 2015. p427; Still, 2011

${ }^{53}$ S. Khan, "Negotiating the Mohalla: Exclusion, Identity and Muslim Women in Mumbai," Economic and Political Weekly xlii, no. 17 pp. 1527-1533 (2007).

${ }^{54}$ Newby, H, The Deferential Worker (London, Allen Lane, 1960)

${ }^{55}$ Dickey, 2012. P. 572
} 
thus more policed. While movement for employment (or education) was facilitated, all other movements, especially movements for leisure and pleasure, were heavily restricted. Participants in Baroda, broadly speaking from middle and upper caste groups, with their economic and cultural resources, are more easily positioned as respectable middle class young women. They report being trusted by their parents and in upholding the limits of 'respectable' behavior.

But women do not simply blindly follow stipulations placed on them, and we found in both our studies examples of women attempting to negotiate the boundaries of 'respectability', or drawing on notions of respectability in order to carve out more freedoms for themselves. We have described how the Dalit women attempt to 'manufacture respectability ${ }^{, 56}$ by wearing more traditional dress and appearing more 'docile' and religious. They also actively questioned restrictions around relationships, sometimes performing respectability in order to enter into illicit relationships. Unlike the middle class women who embrace arranged marriage as a form of symbolic capital, these women prioritise financial security from whatever form of marriage it may come in - though often this was deemed to come via an arranged marriage which ensured enduring affinal ties with their parents. ${ }^{57}$

The middle class women had less reason to 'manufacture respectability', since as middle class affluent young women, they are thought to already embody such ideals. They reported being trusted by their parents and in turn trusting their parents 'knew best' in terms of arranging marriages. They even went so far as to embrace restrictions on their movement and relationships, either by claiming to prefer to be indoors (thus coming home 'early' from parties) or by embracing arranged marriage through rose-tinted romantic lenses. On the whole then, they did not report the kind of subterfuge that the young women from the slum described. Such explicit breaking of parents' trust would have, in fact, invalidated the very respectability which they adhered to. Young women in Baroda appeared to have internalised their parents' views on respectable behaviour and appropriate intimate relationships such that breaking any rules (unspoken though they may be) was unlikely to happen. However, as Phadke et $\mathrm{al}^{58}$ argue,

It is important to remember that despite the success with which women may or may not be able to negotiate their access to public space, this access is always conditional on their maintaining impeccable reputations. Such access is dependent on the largesse of the woman's family and may be withdrawn at any time. It is a concession, not a right.

Thus, while respectability and chastity are nominally associated with the middle classes, this is not to say that middle class women are free to behave as they please. For example, women in Baroda self-exclude from more open public spaces, such as parks at night, which they associate with lower class individuals and which likely their parents would not approve of. Women of all backgrounds then must continually demonstrate their 'respectability' by conforming (or appearing to conform) to mobility and relationship restrictions.

\footnotetext{
${ }^{56}$ Phadke et al 2011, p. 167

${ }^{57}$ See also Grover, 2011

${ }^{58}$ Phadke et al 2011, p. 170
} 


\section{Locale}

The locations within which these young women are living, while closely tied to their class background, also shape their experiences of and resistances to 'respectability'. In Baroda, the young women lived in 'colonies', essentially housing estates, in a medium sized city in Gujarat. Their material resources, such as mobile phones, scooters and disposable money to spend on expensive coffee shops, opened up spaces that enabled them to mix with other young people without the gaze of their family and parents. The more recent forms of consumption evidenced by the rise of malls and airconditioned coffee shops, establish a spatial boundary between middle- and upper middle-class citizens and those from lower socio-economic groups. These spatial boundaries are increasingly impenetrable ${ }^{59}$ manned as they are by guards who ensure only the 'right' sort of person gains entry. Participants in Baroda can move through city spaces 'between home, work, and the new sites of consumption in cocooned transport vehicles along designated arteries, engaging directly with the rest of the population only through casual and fleeting encounters with the working poor who provide essential services. ${ }^{60}$ These spaces then, open up 'outside home' spaces, which parents consider 'safe' from intrusion of lower class men, considered 'dangerous' to their daughters. The high-status consumption of these venues also adds a veneer of respectability to relations between men and women, since they are by definition middle and upper class spaces. ${ }^{61}$ This creates spaces for 'respectable' courtship, usually within the frame of an arranged marriage. Nonetheless, the relative small size of the city mean that these young women still reported feelings of surveillance, even with these spaces opened to them, especially, but not exclusively, those who had family living in Baroda, further discouraging them from participating in pre-marital relationships.

The young women in Mumbai live in a large metropolis but report far more surveillance. The particular set up of the slum, with few doors and windows on the houses, mean that privacy is not easily attained. The slum can also be viewed as a village within a city, a small and closed community within which neighbours are familiar with one another. As noted by Aditya Nigam ${ }^{62}$ in his study in Delhi, the network of communication is particularly strong in subaltern neighbourhoods where people sit outside in the lanes and by lanes and spend their free time to gossip and exchange information and rumours. Likewise, Penny Vera-Sanso argued that poorer families are exposed to greater levels of scrutiny from people living within their neighbourhoods than better-off families, following a comparison of a squatter settlement and a gentrifying neighbourhood in Tamil Nadu. ${ }^{63}$ The many restrictions placed on the young women mean that it is difficult for them to find spaces beyond the community and family gaze. Restrictions were loosened for work or education,

\footnotetext{
${ }^{59}$ A Kothari, "That Common Ground? Education, Marriage and Family in Middle-Class, Urban India" (University of London, 2013).

${ }^{60}$ C. Upadhya, " India's 'New Middle Class' and the Globalising City: Software Professionals in Bangalore, India.," pp 253-268 in The New Middle Classes: Globalising Lifestyles, Consumerism and Environmental Concern, ed. H Lange and L Meier (London: Springer, 2009). P. 264

${ }^{61}$ Twamley, 2014

${ }^{62}$ A. Nigam, "Theatre of the Urban: The Strange Case of the Monkeyman," pp. 22-30 in Sarai Reader 2002, the Cities of Everyday Life, ed. R Vasudevan and et al (Delhi: Serai and CSDS \& The Society for Old and New Media, 2002).

${ }^{63}$ Penny Vera-Sanso, 'Conformity and Contestation: Social heterogeneity in South Indian settlements, pp. 182-205 in de Neve and Donner, Eds, The Meaning of the Local: Politics of Place in Urban India. London: Routledge/Cavendish 2006
} 
but movement for leisure was very difficult for the young women. Similar findings were uncovered by Ranade ${ }^{64}$ amongst poor young Muslim women in Mumbai slums; educational and work opportunities of women were policed fervently, but the surveillance of leisure activities was even more stringent. However, those that do manage to travel outside of the slum, whether by subterfuge or with the permission of their parents, do find spaces of anonymity where they can engage in more 'discreet' or hidden relationships, thus facilitating premarital contact with members of the opposite sex. Though, as commented on by Baroda young women, these courtships tend to take place in less-respected open spaces, under the gaze of disapproving, though anonymous, others.

\section{Pleasure and intimacy}

Lastly, pleasure, or the lack of, can be seen to shape the experiences and strategies of young women in Baroda and Mumbai. The middle class young women, as reported above, have far fewer restrictions on their movement and more disposable income available to them. They 'hang out' in expensive coffee shops and malls, attend large air-conditioned cinemas, and, some of them, attend late night parties and discos. Economic liberalization and shifting notions of 'modernity' and Indianess, have also opened up new practices of intimacy and courtship. ${ }^{65}$ While before the middle classes, influenced by Ghandi Nehru politics, were implicated in discourses around tradition and austerity, they are now associated with upward social mobility, globalisation, and consumerism. ${ }^{66}$ Spontaneous love affairs and youth autonomy are presented in the media as key elements of a modern marriage. ${ }^{67}$ We have described how young middle class women in India enjoy romantic courtship within the 'respectable' arranged marriage ideal. Participants describe their (future) marriages in romantic terms and look forward to companionship and intimacy with their husbands. This form of marriage both conforms to traditional standards of respectability and upholds the moral superiority of arranged over ('lower class') love marriage. This is not to say that premarital relationships were unheard of, but most preferred and were able to foresee romantic practices within an arranged marriage scenario.

The Dalit women in the slum area of Mumbai, on the other hand, describe lives of extreme surveillance, violence and hardship. Such findings of domestic and structural violence experienced by Dalit women are echoed in previous research. ${ }^{68}$ The participants look forward pessimistically to their marriages, anticipating further violence and 'drudgery'. Many are working in very low paid jobs and have little, if any, disposable income. Premarital relationships, despite their 'riskiness', become a way to experience intimacy and pleasure when they foresee no other opportunities for them. These young people are likewise exposed to discourses of romance and

\footnotetext{
${ }^{64}$ S. Ranade, "The Way She Moves: Mapping the Everyday Production of Gender-Space," Economic and Political Weekly 42, no. 17 pp. 1519-1526, (2007).

${ }^{65}$ Donner, 2002; 2016; Twamley, 2014.

${ }^{66}$ Srivastava, 2004

${ }^{67}$ Liechty, 2003, Suitably modern

${ }^{68}$ Anandhi, S., Reproductive bodies and regulated sexuality: Birth control debates in early twentiethcentury Tamil Nadu. pp139-166 In A question of silence? The sexual economies of modern India, edited by M. E. John and J. Nair. (London: Zed Books, 2000); Kapadia, Karin, Siva and her sisters: Gender, caste and class in rural South India. (Oxford: Westview, 1995); Rao 2015
} 
pleasure $^{69}$, and report a desire to experience relationships of companionship ${ }^{70}$, even if they are unable to foresee them within marriage. Then it cannot be surprising that such women are more likely to question the limitations set on them, or that they attempt to break normative rules on premarital relationships, when, they claim, these may be their last experiences of intimacy and pleasure. In a study on sexual practices in rural Gujarat, Mehta et $\mathrm{al}^{71}$ make a similar observation. For the young women in their study, the period between menarche and marriage provides young women with a 'window of opportunity' within which they can focus on their own needs. In Mumbai, we observed that a performance of 'docile femininity', such as by acting shy and subservient, as well as access to mobile phones, enable the young women to start and sustain these clandestine relationships.

\section{Conclusions}

Our analysis, comparing the relationship experiences of young middle class and poor Dalit women, highlights the differing ways in which class and caste intersect with gender to shape the means in which women in India conform and resist to patriarchal systems. In our data notions of respectability were repeatedly drawn on by the young women in positioning themselves in relation to class-based ideals of feminine behaviour. For both groups of women, this results in curbs on their freedom of movement and participation in premarital intimate relationships. The bulk of previous scholarship has described the relative freedoms of lower caste women compared to the stricter restrictions placed on middle and upper caste women. Our findings are more in line with a small group of studies which suggest that amongst some Dalit communities aspiring towards social mobility, restrictions on lower caste and class women may be more heavily enforced. Berreman, for example, states that 'the most severe gender inequalities of all are found among the poor, low-caste groups which are striving for upward mobility'. ${ }^{72}$ In such circumstances, we have found that young Dalit women are called upon to uphold respectability, despite being positioned as largely without it. These conditions lead to heavy surveillance, suspicion and curtailed freedoms.

Furthermore, our comparison illustrates that women's particular circumstances shape the ways in which they react to such restrictions and their ability to self-position as 'respectable'. We argue that middle -class young women strike a 'passive bargain', upholding ideals of respectability thereby shoring up symbolic capital for a 'good' marriage and class privilege. The Dalit women, on the other hand, have less to gain in a passive bargain within the patriarchal system in which they live. For these women, class-attributed respectability is more difficult to acquire and maintain, and any

\footnotetext{
69 Pornographic videos and pictures on mobile phones helped young women gain access to a discourse of sexual desire and pleasure. Additionally, visits to areas outside the slum area exposed young women to a wider youth sexual culture in the city which was less restrictive. For instance, it is not uncommon to see couples in certain areas of the city engage in a public display of affection.

${ }^{70}$ See also Parry 2001 - there is a new ideological stress on the couple and their relationship amongst the 'upper echolons' of the labour classes.

${ }^{71}$ A Mehta, S Schensul, and S Fall, "Public Social Reputation Vs Private Sexual Risk for Young Women in a Rural Area in Gujurat," pp90-108 in Sexuality in the Time of Aids, ed. R.K. Verma, P Pelto, and S Schensul (New Delhi: Sage, 2004).

${ }^{72}$ Page 370, Berreman, Gerald, 'Sanskritization as Female Oppression in India', in Barbara. D. Miller (ed.), Sex and Gender Hierarchies (Cambridge: Cambridge University Press: 1993) p366-392. See also: Kapadia 1995 and Still 2011
} 
resulting outcome likely to offer reduced dividends. In this way, they both conform to and attempt to push the boundaries of 'respectability', questioning the limitations imposed on them and attempting to carve out more freedoms for themselves. As Kandiyoti $^{73}$ writes, the dominant classes have a stake in defending the status quo, while the dominated classes may have more interest in pushing back. In our comparison, both groups are defined and confined by notions of 'respectability', but this plays out and is 'resisted' to different degrees and in differing ways. The analysis produces new insights into the ways that class, caste and location cut across gender, structuring the ways in which Indian women are able to enact and resist gendered norms.

\section{Acknowledgements}

Many thanks to Professor Ann Oakley for her insightful comments on drafts of this article and to the anonymous reviewers for their feedback and suggestions. A very special thank you to those who participated in the research in Baroda and Mumbai. This collaborative article was funded by the UCL Sea and Currents Fund.

\footnotetext{
${ }^{73}$ Kandiyoti, 1988
} 